\title{
The role of parapodia and lack of photoacclimation in kleptoplasts of the sacoglossan sea slug Plakobranchus ocellatus
}

\author{
Angela Richards Donà ${ }^{1}$ ( Jussi Evertsen ${ }^{2} \cdot$ Geir Johnsen $^{3}$
}

Received: 4 August 2021/Accepted: 15 January 2022/Published online: 4 March 2022

(C) The Author(s) 2022

\begin{abstract}
The sacoglossan sea slug Plakobranchus ocellatus is a pantropical gastropod that pilfers and incorporates algal chloroplasts (kleptoplasts) into its digestive cells and benefits from the production of photosynthate. It is a mobile, reef forager with mottled, wing-like parapodia that provide good camouflage in sand and are typically observed closed over the kleptoplast-filled digestive tubules. Functional kleptoplasts continue to photosynthesize but are separated from the algal nuclei and are unable to divide within host cells. The mechanisms that enable kleptoplasts to endure are poorly understood and the extent and limitations of functionality have not yet been fully characterized. We investigated kleptoplasts in three tropical sacoglossan species, Elysia ornata, Thuridilla gracilis, and $P$. ocellatus, collected from different depths and light fields to identify pigments, quantify retention times, and determine photosynthetic parameters. We found that $P$. ocellatus had the highest estimated retention time and maintained the highest ratio of photoprotective to photosynthetic pigments. A subsequent manipulative experiment on P. ocellatus specimens collected at the same site, depth,
\end{abstract}

Topic Editor Simon Davy

Angela Richards Donà

angelard@hawaii.edu

1 Hawai'i Institute of Marine Biology, University of Hawai 'i at Mānoa, Honolulu, HI 96822, USA

2 Department of Natural History, NTNU University Museum, Norwegian University of Science and Technology, Trondheim, Norway

3 Centre of Autonomous Marine Operations and Systems, Trondhjem Biological Station, Department of Biology, Norwegian University of Science and Technology, Trondheim, Norway and time involved exposure to three different irradiances and showed that kleptoplasts did not photoacclimate over the course of $7 \mathrm{~d}$. No significant changes in in vivo kleptoplast photosynthetic parameters or corresponding spectral reflectance occurred when measuring kleptoplasts directly with open parapodia. Reflectance of closed parapodia, however, showed significant increases in the medium- and high-light treatments on day seven indicating localized kleptoplast degradation. Our results suggest that closed parapodia play an important role in kleptoplast protection by shielding internal kleptoplasts while permitting filtered light energy to reach kleptoplasts on the parapodial undersides. The cryptically patterned parapodia assume the role of photoprotectant, compensating for kleptoplast inability to photoacclimate. This allows $P$. ocellatus to forage in high-light, exposed, sandy areas and exploit algal food resources that may be unavailable or too risky for other sacoglossans.

Keywords Photoacclimation - Sacoglossans - Kleptoplast · Pulse-amplitude-modulated fluorometry $\cdot$ Light saturation parameter $\left(\mathrm{E}_{\mathrm{k}}\right)$

\section{Introduction}

Sacoglossan gastropods (Mollusca, Opisthobranchia) are suctorial marine herbivores that remove functional chloroplasts from a variety of algal food sources (Christa et al. 2014; Wade and Sherwood 2017) and relocate them to digestive cells without digestion. This remarkable ability (Händeler et al. 2009; Raven et al. 2009) permits the sea slugs to utilize the photosynthate produced by the stolen chloroplasts ("kleptoplasts") to fuel their own metabolism (Trench et al. 1969; Cruz et al. 2020). Once separated from 
their algal cells and nuclei, kleptoplasts continue to absorb light energy and produce photosynthate (Walker 1970; Trench and Ohlhorst 1976) but experience a decrease in chlorophyll $a(\mathrm{Chl} a)$ fluorescence and photosynthetic activity over time, consistent with an inability to divide (Trench and Ohlhorst 1976; Evertsen et al. 2007). Previous investigations on the retention of functional chloroplasts (RFC) in sacoglossans estimated that kleptoplasts remain in hospite and functional for periods ranging from $1 \mathrm{~h}$ to over 3 months (Evertsen et al. 2007; Pierce et al. 2015). This wide range indicates different retention strategies from prompt chloroplast consumption to the long-term optimization of kleptoplast functionality. We do not yet understand, however, the factors that determine retention times and survivability, or whether these factors are driven by the host, the kleptoplasts, or both. Nor do we have a good understanding of the ecological importance of kleptoplasts in sacoglossans, the drivers that determine sacoglossan foraging preferences, or their abilities to travel between different light intensity regimes.

Intact algal chloroplasts have highly plastic pigment pools and are able to photoacclimate to changes in the light field largely through concentration changes in pigments from two functional categories: light-harvesting (photosynthesis) and photoprotective (Escoubas et al. 1995; Sakshaug et al. 1997; Rodríguez et al. 2006; Brunet et al. 2011). This ability to photoacclimate is fundamental for chloroplast optimization and survival in intact algal systems (Falkowski and Raven 2007) and is presumed to be similarly important in in hospite kleptoplasts. The original light acclimation status of the algal chloroplasts has important consequences for functionality within the new host and may restrict hosts to similar light gradients (Cartaxana et al. 2018). Previous research suggests that once separated from the algal cellular components, kleptoplasts are unable to photoacclimate to changes in irradiance (Serôdio et al. 2014). Neither division nor pigment synthesis was observed in exposed kleptoplasts of E. viridis (Evertsen and Johnsen 2009), whereas exposed kleptoplasts in Elysia chlorotica appear to synthesize chlorophyll $a(\mathrm{Chl}$ $a$; Pierce et al. 2009) and some important PSU proteins (Pierce et al. 1996). We sought to better understand kleptoplast functionality by investigating whether kleptoplasts in three tropical sacoglossans (with exposed and cloaked kleptoplasts) can photoacclimate.

Photoacclimation is a process of reversible physiological alteration in the number, size, and/or position of chloroplasts and/or their light harvesting and photoprotective pigments in photosynthetic units (PSU) within cells (Escoubas et al. 1995; Rodríguez et al. 2006). Long-term photoacclimation processes involve structural and compositional changes, whereas short-term photoacclimation can be accomplished through activation of the xanthophyll cycle (XC), which is a primary method of non-photochemical fluorescence quenching (NPQ) in most photosynthetic organisms (Brunet et al. 2011). Pigment or size changes within the PSU affect spectral light absorption and utilization and the rate of electron transfer and may occur on timescales of minutes to days (Escoubas et al. 1995; Falkowski and Chen 2003; Hamel and Smith 2020). Photoacclimation in functional chloroplasts allows optimization of growth rates (through division) under a wide range of irradiances while maintaining relatively steady rates of photosynthesis (Brunet et al. 2011). Chloroplast pigment concentrations are modulated by light, resulting in a larger pool of photoprotective pigments produced in high-lightacclimated chloroplasts (Kirk 2011). If relative concentrations of photoprotective and light harvesting pigments in kleptoplasts are "frozen" in their original light-acclimated state, and long-term RFC is the goal, sacoglossans may be limited to light fields matching the original algal chloroplast acclimation status. Slugs that can shield their kleptoplasts with parapodia may be able to circumvent irradiance boundaries and achieve long-term RFCs without photoacclimation.

Most sacoglossans feed on and retain chloroplasts originating from coenocytic or siphonous algal species (DeWreede 2006; Leliaert et al. 2012) within the Bryopsidales (= Caulerpales; Jensen 1997), and the Dasycladales (Marín and Ros 1992). Recent studies in Hawai ‘ $i$ showed that $P$. ocellatus incorporates chloroplasts from 23 different siphonous green algal sources, preferring epilithic, diminutive species (Wade and Sherwood 2017, 2018), many of which grow beneath the sand (RM Wade, pers. comm). Algal pigments include major chlorophylls (e.g., Chl $a$, Chl $b$, and divinyl $a$ and $b$, and the Chl $c$ group), > 30 major carotenoids (carotenes and xanthophylls), and three major phycobiliprotein groups (allophycocyanins, phycocyanins, and phycoerythrins (Roy et al. 2011). Siphonaxanthin and its ester, siphonein, are exclusive to the green algal order Bryopsidales (Yokohama 1981; Roy et al. 2011), which is characterized by coenocytic and siphonous thallus construction, ideal for the sacoglossan feeding strategies (Jensen 1993; Hirose 2005). These carotenoids are generally accepted to serve light harvesting and energy transfer functions for photochemistry (Rowan 1989). Various other carotenoids harvest light but have lower energy transfer efficiency and thus serve more commonly in the photoprotective role, dissipating heat through quenching of excited-state chlorophylls and radical oxygen species (ROS) or through cyclic de-epoxidation and epoxidation of xanthophylls (xanthophyll cycle or XC; Krause and Weis 1991; Baker 2008; Taiz and Zeiger 2010). Carotenoids, like chlorophylls and other photosynthetic pigments, are located in the light-harvesting complexes of both photosystems and help regulate light energy flow to 
reaction centers and/or manage the damaging products of excess excitation at the reaction centers (Taiz and Zeiger 2010).

We took a multifaceted approach-employing photochemical, chemotaxonomic, and spectroscopic measurement techniques - to better understand the photoacclimatory capability (and by extension, the importance of full functionality) of kleptoplasts in these enigmatic solarpowered sea slugs.

\section{Materials and methods}

Pulse-amplitude-modulated (PAM) fluorometry, which imposes minimal disturbance on the experimental organisms, was used to examine several photosynthetic parameters in sacoglossans to determine their kleptoplast capacity for photoacclimation. The light saturation parameter $\left(E_{k}\right)$, photosynthetic efficiency parameter $(\alpha)$, optimal quantum yield $\left(F_{v} / F_{m}\right)$, and relative maximum electron transport rate $\left(\mathrm{rETR}_{\max }\right)$ were analyzed to determine whether changes in irradiance would induce a corresponding photoacclimation response. High-precision liquid chromatography (HPLC) was used to isolate diagnostic pigments from known algal groups to identify the kleptoplast constituents and compile a composition inventory divided into photosynthetic and photoprotective groups. Modular spectrometers are highly effective at obtaining rapid, noninvasive in vivo spectral reflectance (R) measurements to identify pigment absorbance peaks. We examined known kleptoplast pigment absorbance peaks (or reflectance troughs) and compared these over time to determine whether shifts in pigment composition occurred. Optimization of photoprotective to photosynthetic pigment ratios paired with corresponding changes in photosynthetic parameters may be interpreted as signs of photoacclimation to a new irradiance regime (Brunet et al. 2011).

During initial mensurative studies conducted at Lizard Island Research Station, Great Barrier Reef, Australia (LIRS; $14^{\circ} 40^{\prime} \mathrm{S}, 145^{\circ} 28^{\prime} \mathrm{E}$ ), we identified the constitutive pigments in kleptoplasts and measured in vivo photosynthetic function over time to determine host RFC levels in three tropical sacoglossan species Plakobranchus ocellatus (van Hasselt 1824) and Thuridilla gracilis (Risbec 1928), which are rarely observed with kleptoplasts exposed, and Elysia ornata (Swainson 1840; Fig. 1). Notably, Thuridilla (Bergh 1872) has recently been described as a species complex (Martín-Hervás et al. 2021), and the species complex Plakobranchus ocellatus is under taxonomic revision. Plakobranchus ocellatus remains the currently accepted name for the Australian and Hawaiian specimens (Krug et al. 2013; WoRMs; Yonow and Jensen 2018).
LIRS specimens were collected at two separate time points in Austral winter (June 2003-Group 1) and Austral summer (January 2006-Group 2), representing a difference of roughly $2 \mathrm{~h}$ of total daylight. A subsequent manipulative experiment testing capacity for photoacclimation to low(LL) and high-light (HL) conditions was conducted over a 7-d period using $P$. ocellatus specimens collected at the same time, and from the same depth and $10 \mathrm{~m}^{2}$ reef area. This second experiment, run at Hawai' $i$ Institute of Marine Biology at Kāne'ohe Bay, Hawai'i (HIMB), sought to resolve the issue of variability in depth-related original light acclimation states. Several investigations have reported an apparent lack of photoacclimation capacity in primarily temperate sacoglossan kleptoplasts (Vieira et al. 2009; Jesus et al. 2010; Serôdio et al. 2014), but none have tested it directly in tropical specimens from the same size group, collected from the same depth and area, within the same 30-min period. These unique collection conditions permitted direct testing of photoacclimation in similarly light-acclimated kleptoplasts without confounding biological or habitat-induced variability. Physical changes that comprise long-term photoacclimation occur within days and would be detectable in the HL and LL treatments before the conclusion of the 7-d experiment (Falkowski and Owens 1980; Sukenik et al. 1990; Escoubas et al. 1995). In vivo PAM fluorometry and spectral reflectance measurements were used to determine whether kleptoplasts could respond to new light regimes.

\section{Mensurative study}

LIRS sacoglossans were collected in shallow water (1-8 m depth) within the reef barriers and lagoons. Slugs were kept in aquaria with running seawater with in situ temperatures ranging from $24-25{ }^{\circ} \mathrm{C}$ in June to $30-31{ }^{\circ} \mathrm{C}$ in January under natural light conditions (maximum 250-300 $\mu \mathrm{mol}$ photons $\mathrm{m}^{-2} \mathrm{~s}^{-1}$ ). No access to food was provided.

Rapid light-response curves (RLCs) were measured with a Diving-PAM (Heinz Waltz GmbH,

Germany) on slugs that had been dark-acclimated for 15 min (Wägele and Johnsen 2001). A slide projector with a 150-W halogen lamp and slides made from layered plankton-net were used to create 12-15 neutral density filters with increasing irradiances levels. Levels were verified with a RAMSES ACC underwater spectroradiometer at 350-800 nm (Trios GmbH, Germany). Irradiance during experiments was determined from inside the vials with the Diving-PAM $\mathrm{E}_{\mathrm{PAR}} 2 \pi$ irradiance sensor. Measurements took place between $18: 00$ and 20:00 to estimate photosynthetic performance during the end of the illumination phase each day. Individual sacoglossans were placed into separate 24-mL glass vials inserted in white Styrofoam wells for even light distribution. Black rubber barriers were 

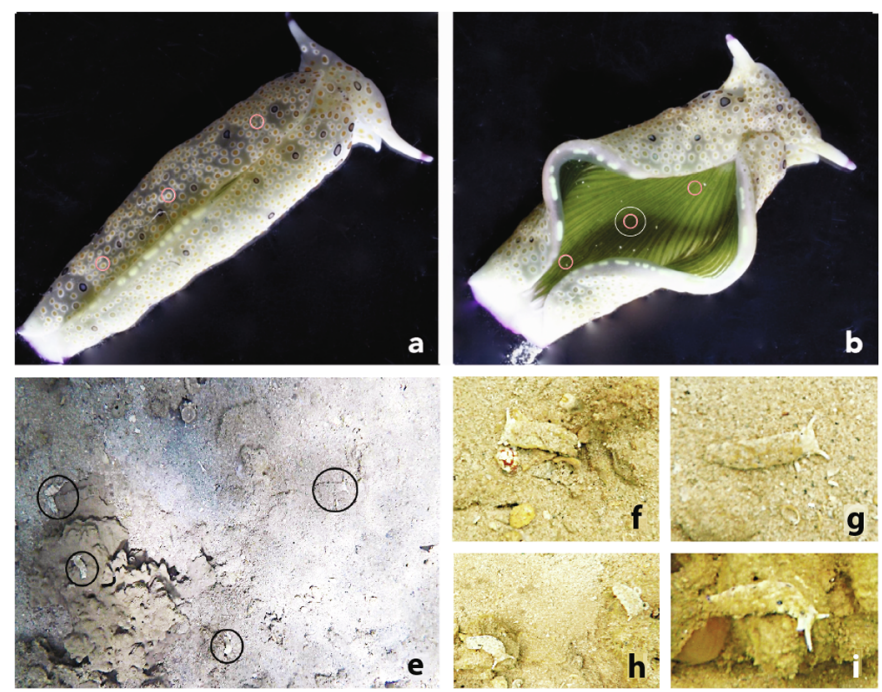

Fig. 1 Three tropical sacoglossan species: Plakobranchus ocellatus $(\mathbf{a}, \mathbf{b}, \mathbf{e}-\mathbf{i})$ with closed parapodia except (b) with manually opened parapodia exposing internal lamellae and kleptoplast-filled digestive tubules. a Body length $\sim 50 \mathrm{~mm}, \mathbf{b} \sim 25 \mathrm{~mm}$. Thuridilla gracilis (c,

positioned between vials to prevent stray light beyond the active measuring site. The dark-acclimated and illuminated fluorescence minima ( $F_{o}$ and $F_{o}$, , respectively) were obtained with a weak non-actinic measuring pulse $(0.15$ $\mu \mathrm{mol}$ photons $\mathrm{m}^{-2} \mathrm{~s}^{-1}$ ) from a light-emitting diode (LED with peak emission at $650 \mathrm{~nm} ; 0.6 \mathrm{KHz}$ in dark (Wägele and Johnsen 2001). Saturating pulses of light $(\sim 10,000$ $\mu \mathrm{mol}$ photons $\mathrm{m}^{-2} \mathrm{~s}^{-1}$ for $0.8 \mathrm{~s}$ duration) from a halogen lamp oxidized all $\mathrm{RC}_{\mathrm{PSII}}$ to obtain measurements of $F_{m}$ (dark-acclimated fluorescence maximum) and $F_{m}$ ' (illuminated fluorescence maximum) during the nine-step RLC with increasing values of actinic light at each step. 2-min incubation times were used between saturating pulses and placement of the PAM probe assured minimal movement and the parapodia remained open during measurements. The relative electron transport rate (rETR) is defined as $\Phi_{\text {PSII }}$ multiplied by the incident irradiance at each saturating pulse: $\mathrm{rETR}=\Phi_{\mathrm{PSII}} * \mathrm{E}_{\mathrm{PAR}}$, and was used to obtain information on kleptoplast photoacclimation ability. Curve fitting was done in Sigmaplot version 10.0 according to the equation by Webb et al. (1974). We also calculated $E_{k}$ $\left(\mu \mathrm{mol}\right.$ photons $\mathrm{m}^{-2} \mathrm{~s}^{-1}$ ) as the ratio of $\mathrm{rETR}_{\max } / \alpha$ (initial slope of light curve; Genty et al. 1989; Kroon et al. 1993; Sakshaug et al. 1997).

RFC was estimated for the Group 1 (June) specimens, which were kept for up to $12 \mathrm{~d}$ without access to food. Rapid light-response curves for Group 2 (January) specimens were run only once before each was sacrificed for pigment extraction. RLCs were conducted $1-2 \mathrm{~d}$ after the slugs were collected to permit acclimation to aquaria conditions. The initial $\Phi_{\text {PSII }}$ was calculated from the
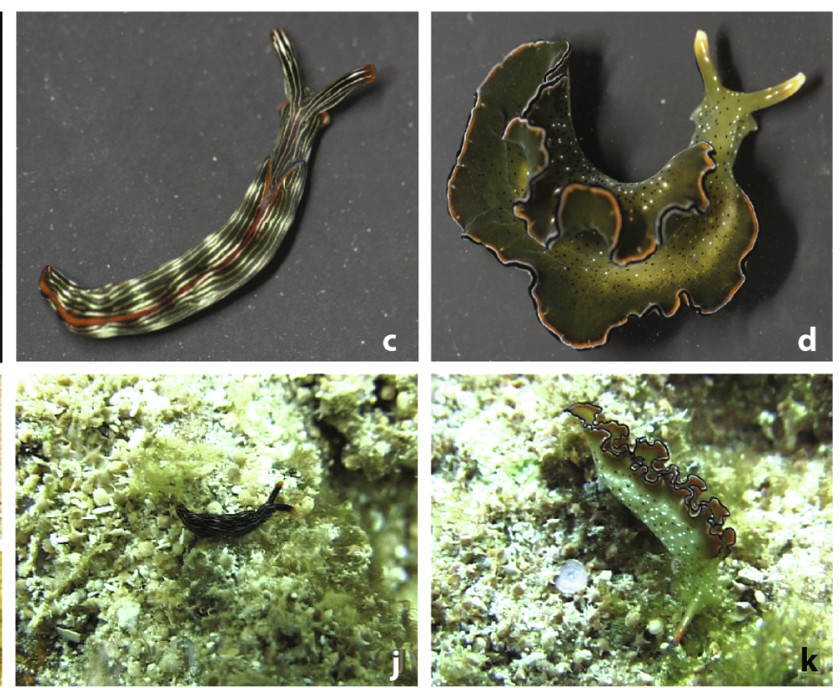

$\mathbf{j} ; \sim 30 \mathrm{~mm}$ ), and Elysia ornata $(\mathbf{d}, \mathbf{k} ; \sim 45 \mathrm{~mm})$. Top photographs taken in laboratory, bottom at collection sites. Small pink circles a, b indicate targeted areas for reflectance probe $(6.35 \mathrm{~mm})$ and larger white circle (b) for PAM probe $(5 \mathrm{~mm})$

regression line intercepting the $y$-axis and the daily decrease was estimated by linear regression.

All in vitro pigment preparations were analyzed under low light to avoid pigment degradation. At LIRS, Group 2 slugs and algae were measured for wet weight, then gently dried with adsorbent paper to avoid a reduction in extraction efficiency. Each was wrapped in aluminum foil and stored in liquid nitrogen for pigment extraction and HPLC analysis at Trondhjem Biological Station (TBS). Frozen specimens were transferred to glass vials with $2-4 \mathrm{ml}$ precooled methanol bubbled with $\mathrm{N}_{2}$ to avoid oxidation. Tissue was ground with a glass rod allowing $24 \mathrm{~h}$ of pigment extraction in darkness at $4{ }^{\circ} \mathrm{C}$. After extraction, the samples were filtered through a $0.45-\mu \mathrm{m}$ Millipore filter to remove debris, and $150 \mu \mathrm{l}$ pigment extract was injected into the HPLC system (Hewlett-Packard HPLC Series 1100), following published separation and quantification protocol (Rodríguez et al. 2006). Chlorophylls and carotenoids were detected by absorbance at $420,440,460$, and $480 \mathrm{~nm}$ and identified by a diode array absorbance detector (350-750 nm with $1.2 \mathrm{~nm}$ spectral resolution). HPLC pigment calibration was performed using Chl $a$ and $\beta, \varepsilon-$ carotene standards from SIGMA (Aldrich, UK) and chlorophyll and carotenoid standards ( $\mathrm{Chl} b, \mathrm{Chl} c^{1}$, violaxanthin, neoxanthin, siphonaxanthin, and siphonein) developed in TBS laboratory. The extinction coefficient of $250 \mathrm{~L} \mathrm{~g}^{-1} \mathrm{~cm}^{-1}$ at $445 \mathrm{~nm}$ in acetone for $\beta, \beta$-carotene (Jeffrey et al. 1997) was used for the calculation of $\mu \mathrm{g}$ siphonaxanthin and siphonein, adjusting for differences in molecular weight between carotenoids (Johnsen and Sakshaug 2007). Additional specific extinction coefficients were also used (Roy et al. 2011). 


\section{Manipulative experiment}

Forty-eight specimens of Plakobranchus ocellatus were collected from the fringing reef off Kokokahi in south Kāne'ohe Bay, O'ahu $\left(21^{\circ} 414^{\prime} \mathrm{N},-157^{\circ} 78^{\prime} \mathrm{W}\right)$. All similar-sized specimens were collected from a $\sim 10 \mathrm{~m}^{2}$ area of the reef at $\sim 1.5 \mathrm{~m}$ depth. Individual slugs were placed in water-filled Whirl-Pak sampling bags (Nasco, WI, USA) for transportation to the Coral Reef Ecology Laboratory (CREL) at the Hawai' $i$ Institute of Marine Biology (HIMB). Irradiance (E) measurements were taken in full sun at approximately solar noon at the site of collection above the water surface, $\sim 5 \mathrm{~cm}$ below the surface, and $\sim 1.5 \mathrm{~m}$ depth with a LI-250A light meter attached to an underwater cosine sensor (LI-COR, NE, USA). $\mathrm{E}_{\text {PAR }}$ (Photosynthetic Active Radiance, 400-700 nm) values measured $\sim 1800, \sim 1250$, and $\sim 900 \mu \mathrm{mol}$ photons $\mathrm{m}^{-2}$ $\mathrm{s}^{-1}$, respectively.

All specimens were placed in individual tricorner polypropylene beakers in a flow-through water table at the laboratory. Foam cubes affixed to each corner of the eighteen $250-\mathrm{mL}$ beakers provided flotation, and three small holes were punctured into the beakers to permit inward water flow and uniform in situ temperature and to prevent osmotic stress due to evaporation. Six beakers were placed in each of three treatments in the aerated water table filled to approximately $12 \mathrm{~cm}$ from the flow-through system. Each treatment was separated with PVC pipes that functioned as dividers and float support and each was flanked by water-filled aquaria. From the bulk specimen collection, 18 individuals were randomly placed - one in each beaker-and assigned to a treatment: high light $(\mathrm{H})$, medium light $(\mathrm{M})$, and low light $(\mathrm{L})$. The remaining specimens were divided equally into the three treatments and placed in the corresponding aquaria as alternates in case of mortality. The $\mathrm{H}$ treatment beakers and aquaria remained unshaded, the $\mathrm{M}$ treatment was covered in shade cloth reducing ambient light $\sim 71 \%$, and the $\mathrm{L}$ treatment reduced light $\sim 96 \%$. Irradiance maxima in partial and full sun ranged from $\sim 880-2100(\mathrm{H}), \sim 255-600(\mathrm{M})$, and 25-80 (L) $\mu \mathrm{mol}$ photons $\mathrm{m}^{-2} \mathrm{~s}^{-1}$. The specimens were kept without food for the entire 8-d (D1-8) experiment.

On D1, nine specimens from the bulk collection were dark-acclimated for $15 \mathrm{~min}$ for initial in vivo Chl $a$ fluorescence kinetics measurements with Diving-PAM and WinControl-3.25 software. One rapid light-response curve (RLC) per specimen was run with saturating pulses at 30-s intervals and increasing actinic irradiances to $1000 \mu \mathrm{mol}$ photons $\mathrm{m}^{-2} \mathrm{~s}^{-1}$. The intensity of the blue light-emitting measuring probe $\left(470 \mathrm{~nm}\right.$, LED, $0.05 \mu \mathrm{mol}$ photons $\mathrm{m}^{-2}$ $\mathrm{s}^{-1}$ ) did not induce photosynthetic activity. Three specimens from this group were randomly assigned, with an additional three specimens, to each treatment $(n=6)$. All specimens were acclimated to their new light environments for $48 \mathrm{~h}$ before subsequent PAM and reflectance measurements. The external surface of parapodia produced low fluorescence signal and high noise; thus, only internal kleptoplasts in digestive lamellae were measured.

In vivo reflectance $(\mathrm{R})$ spectra were collected in random order on D3, D5, and D7 with an R400-7-SR $400 \mu \mathrm{m}$ reflectance probe attached to a Flame S-UV-VIS-ES 200-850 nm modular spectrometer and a Mikropack Deuterium-Halogen DH-2000 UV-VIS-NIR light source (all Ocean Insight-formerly Ocean Optics, Dunedin, FL, USA). Prior to measurements, $100 \%$ reflectance was determined using the OceanView version 4.1 software wizard and the WS-1 reflectance standard, to provide a baseline. Three spectral reflectance measurements-adjacent to the pericardial swelling, central, and distal-were recorded per specimen to properly represent variable kleptoplast density on the internal lamellae and external parapodial surface (Fig. 1). Relevant chlorophyte wavelengths 438 (Chl $a, b$ and carotenoids), 470 (Chl $b$ and carotenoids), 550 (low absorption window of all pigments), $645(\mathrm{Chl} b)$, and $678 \mathrm{~nm}(\mathrm{Chl} a)$ were used for statistical comparison per Beach et al. (2006) and Serôdio et al. (2010). All specimens were alive and mobile when returned to the reef at the conclusion of the experiment.

\section{Statistical analysis}

Photosynthetic parameter and spectral reflectance data were extracted and sorted using Python 3 scripts in PyCharm version 11.0.5. After verification that all initial specimens $(n=9)$ had similar rates of photosynthesis, we used Welch's one-way ANOVA $(\alpha=0.05)$ allowing for unequal variances in JMP Pro version 16 (SAS) to compare final day (D7) photosynthetic parameters by treatment $(n=$ 6). Relative electron transport rate (rETR) curves (from PAM RLCs) were plotted in RStudio version 1.2.5042 "Double Marigold" using the Phytotools package version 1.0 and the model "fitWebb" (Webb et al. 1974). Mean spectral reflectance data for the three measurements each of open and closed parapodia were smoothed with the Savitzky-Golay filter and compared D7 to D3 using nonparametric Wilcoxon/Kruskal-Wallis rank sums tests at five wavelengths, including $438 \mathrm{~nm}$ (Chl $a$ maximum absorption in blue portion of spectrum), $470 \mathrm{~nm}, 550 \mathrm{~nm}$, $645 \mathrm{~nm}$, and $678 \mathrm{~nm}$ (Chl $a$ maximum absorption in red). Figures were produced in RStudio, JMP, and Adobe Illustrator. 


\section{Results}

\section{LIRS Australia-mensurative study}

\section{In vitro Pigments-chemotaxonomy and function}

The pigment composition of the three sacoglossan species showed that all contained $\mathrm{Chl} a, \mathrm{Chl} b$, siphonaxanthin, siphonein, neoxanthin, violaxanthin, and $\beta, \varepsilon$-carotene, indicative of the green Bryopsidales. Additionally, $P$. ocellatus and E. ornata contained 19'hexanoyloxyfucoxanthin, diatoxanthin and a mix of unknown carotenoids potentially from microphytobenthos, i.e., diatoms or epiphytic haptophytes on the food algae. Plakobranchus ocellatus also contained lutein, and an anthera-like carotenoid, not found in E. ornata or T. gracilis. The ratio $(\mathrm{W}: \mathrm{W})$ between photosynthetic and photoprotective pigments was 4.31 in P. ocellatus, 7.09 in E. ornata, and 15.62 in $T$. gracilis when considering violaxanthin as a photoprotective carotenoid. Plakobranchus ocellatus has the highest number of photoprotective to photosynthetic pigments among the three species even when violaxanthin is tallied with photosynthetic pigments (Table 1).

\section{Retention of functional chloroplasts (RFC)}

RFC values for the three sacoglossan species were estimated based on a daily decrease in $\Phi_{\text {PSII }}$ of $4-6 \%$ in $P$. ocellatus, $67-100 \%$ decrease in E. ornata, and 76-94\% decrease in $T$. gracilis (Fig. 2). RFC for $P$. ocellatus $(n=3)$ was 197-277 d based on $\Phi_{\text {PSII }}$ decrease of 0.003-0.004 d $\mathrm{d}^{-1}$ (y-intercept $0.79 \Phi_{\mathrm{PSII}}$ estimated from regression line, $\mathrm{R}^{2}=$ $0.33)$. RFC for E. ornata $(n=3)$ was $8-12$ d based on $\Phi_{\text {PSII }}$ decrease of $0.039-0.042 \mathrm{~d}^{-1}$ (y-intercept $0.67 \Phi_{\text {PSII }}$ estimated from regression line, $\mathrm{R}^{2}=0.47$ ), and $12-14 \mathrm{~d}$ for $T$. gracilis $(n=2)$ based on $\Phi_{\text {PSII }}$ decrease of $0.037-0.048 \mathrm{~d}^{-1}$ (y-intercept $0.57 \Phi_{\mathrm{PSII}}$ estimated from regression line, $\mathrm{R}^{2}=$ $0.61)$.

An inability for several specimens of each species to reach light saturation-even at actinic irradiances up to $1200 \mu \mathrm{mol}$ photons $\mathrm{m}^{-2} \mathrm{~s}^{-1}$-hindered estimations of $\mathrm{rETR}_{\max }$, and wide value ranges in the calculated photosynthetic parameters $\mathrm{rETR}_{\max }, \alpha$, and $\mathrm{E}_{\mathrm{k}}$, made analysis and interpretation of these results problematic (Table S1). For instance, $\mathrm{E}_{\mathrm{k}}$ in P. ocellatus ranged from 100 to 2219 , a 20 -fold difference that highlights the importance of original kleptoplast acclimation status within the slugs collected at different depths and light fields.

\section{HIMB Hawai'i-photoacclimation experiment}

In vivo photosynthetic parameters and spectral reflectance in Plakobranchus ocellatus

Relative $\mathrm{ETR}_{\max }, \mathrm{E}_{\mathrm{k}}, \alpha$, and $\mathrm{F}_{\mathrm{v}} / \mathrm{F}_{\mathrm{m}}$ were analyzed as photosynthetic parameters for inter- and intraspecific comparison between specimens from the three light level treatments (Table 2). It was impossible to obtain reliable RLC data on closed parapodia due to a low Chl $a$ fluorescence signal to noise ratio; thus, the photosynthesis results reflect status of internal kleptoplasts only. We found no statistically significant changes in any of the treatments for any of the parameters as a function of time. Plots of rETR vs irradiance curves for all treatments and times demonstrate a generally homogeneous response among the treatments with most rETR values between 200 and 400 (dimensionless) at the final saturating pulse and maximum actinic value of $1000 \mu \mathrm{mol}$ photons $\mathrm{m}^{-2} \mathrm{~s}^{-1}$ (Fig. 3). Only $\sim 48 \%$ of all specimens reached saturation prior to the final saturating pulse. Notably, the maximum actinic irradiance applied during RLCs was ecologically relevant since it was close to the ambient maximum downwelling irradiance measured $\left(\sim 900 \mu \mathrm{mol}\right.$ photons $\left.\mathrm{m}^{-2} \mathrm{~s}^{-1}\right)$ in the slug habitat.

Reflectance measurements were taken for internal kleptoplasts of open parapodia and the external surface of closed parapodia. We looked for lateral shifts in peaks, which indicate changes in photoprotective to photosynthetic ratios, as well as basic increases or decreases in in vivo reflectance by analyzing several wavelengths over time. In open parapodia, no significant differences in kleptoplast reflectance were found at any wavelength in any of the treatments. In closed parapodia, we observed statistically significant increases in reflectance from D3 to D7 at all analyzed wavelengths in the $\mathrm{H}$ and at two wavelengths in the $\mathrm{M}$ treatments (Table 3). There were no significant changes in the $\mathrm{L}$ treatment. Figure 4 illustrates reflectance at $678 \mathrm{~nm}$ of internal and external slug surfaces revealing low and mostly stable reflectance in internal versus higher and more dynamic reflectance on the external surface of parapodia as a function of time. Higher reflectance is equivalent to lower absorbance (transmittance is considered negligible), consistent with a loss or degradation of Chl $a$ and other pigments in kleptoplasts. Reflectance spectra for the six specimens per day per treatment were plotted as mean values for open (Fig. 5a, c, e) and closed parapodia (Fig. 5b, d, f). These spectra show clear increases in reflectance in the closed but no clear peak shifts in either open or closed parapodia. All spectra remained similarly shaped over time. 
Table 1 Pigment composition identified and quantified by HPLC, in the three LIRS sacoglossan species with most observed parapodial state (open or closed) denoted.

\begin{tabular}{|c|c|c|c|c|c|c|c|}
\hline \multirow{3}{*}{\multicolumn{2}{|c|}{$\frac{\text { Wet weight }(\mathrm{g}) \text { mean/CV\% }}{\text { Total pigment composition }}$}} & \multirow{2}{*}{\multicolumn{2}{|c|}{$\begin{array}{l}\text { Plakobranchus ocellatus } \\
\text { Parapodia closed }\end{array}$}} & \multirow{2}{*}{\multicolumn{2}{|c|}{$\begin{array}{l}\text { Thuridilla gracilis } \\
\text { Parapodia closed }\end{array}$}} & \multirow{2}{*}{\multicolumn{2}{|c|}{$\begin{array}{l}\begin{array}{l}\text { Elysia ornata } \text { Parapodia } \\
\text { open }\end{array} \\
0.366 / 54\end{array}$}} \\
\hline & & & & & & & \\
\hline & & \multirow{2}{*}{$\begin{array}{l}\mu \mathrm{g} \text { pigm/g } \\
\text { slug } \\
\text { Mean/CV\% }\end{array}$} & \multirow{2}{*}{$\begin{array}{l}\mu \mathrm{g} \operatorname{pigm} / \mu \mathrm{g} \\
\text { Chl a } \\
\text { Mean/CV\% }\end{array}$} & \multirow{2}{*}{$\begin{array}{l}\mu \mathrm{g} \operatorname{pigm} / \mathrm{g} \\
\text { slug } \\
\text { Mean/CV\% }\end{array}$} & \multirow{2}{*}{$\begin{array}{l}\mu \mathrm{g} \operatorname{pigm} / \mu \mathrm{g} \\
\text { Chl a } \\
\text { Mean/CV\% }\end{array}$} & \multirow{2}{*}{$\begin{array}{l}\mu \mathrm{g} \operatorname{pigm} / \mathrm{g} \\
\text { slug } \\
\text { Mean/CV\% }\end{array}$} & \multirow{2}{*}{$\begin{array}{l}\mu \mathrm{g} \text { pigm } / \mu \mathrm{g} \\
\text { Chl a } \\
\text { Mean/CV\% }\end{array}$} \\
\hline Pigments & $\begin{array}{l}\text { In vitro absorption } \\
\text { maxima }\end{array}$ & & & & & & \\
\hline Chl $a$ & $\begin{array}{l}411,430,536,580,616,662 \\
\quad[1.22]\end{array}$ & $73.44 / 53$ & $1.00 / 0$ & $127.28 / 169$ & $1.00 / 0$ & $45.61 / 66$ & $1.00 / 0$ \\
\hline Chl $a$-like & $\begin{array}{l}411,431,535,582,617,663 \\
\quad[1.30]\end{array}$ & $2.47 / 127$ & $0.03 / 97$ & 0 & 0 & $2.20 / 173$ & $0.04 / 173$ \\
\hline Chl $b$ & $(425), 457,596,645$ [2.79] & $26.20 / 41$ & $0.37 / 12$ & $56.84 / 153$ & $0.54 / 27$ & $18.97 / 64$ & $0.45 / 22$ \\
\hline Chl $b$-like & $(430), 457,595,646$ [3.65] & $1.33 / 77$ & $0.02 / 50$ & 0 & 0 & 0 & 0 \\
\hline Pheophytin a & $\begin{array}{l}411,507,536,608,666 \\
{[2.49]}\end{array}$ & $1.21 / 245$ & $0.01 / 245$ & 0 & 0 & 0 & 0 \\
\hline Siphonaxanthin & $449,(470)$ & $0.63 / 118$ & $0.01 / 145$ & $1.88 / 197$ & $0.01 / 104$ & $3.84 / 54$ & $0.10 / 40$ \\
\hline Siphonein & $456,(476)$ & $1.74 / 31$ & $0.03 / 32$ & $13.61 / 58$ & $0.27 / 105$ & $1.44 / 73$ & $0.04 / 40$ \\
\hline Neoxanthin & $415,439,467[0.91]$ & $7.50 / 28$ & $0.12 / 43$ & $0.45 / 283$ & $0.01 / 283$ & $6.69 / 34$ & $0.20 / 66$ \\
\hline Neo-like & $414,436,464[0.66]$ & $0.48 / 94$ & $0.01 / 114$ & 0 & 0 & 0 & 0 \\
\hline *Violaxanthin & $417,442,471[0.97]$ & $9.34 / 12$ & $0.15 / 35$ & $10.52 / 159$ & $0.10 / 53$ & $0.99 / 30$ & $0.04 / 116$ \\
\hline *Viola-like & $418,443,472[0.89]$ & 0 & 0 & 0 & 0 & $1.99 / 28$ & $0.08 / 108$ \\
\hline Lutein & $(423), 448,476[0.63]$ & $3.97 / 49$ & $0.06 / 59$ & 0 & 0 & 0 & 0 \\
\hline Anthera-like & $(423), 448,476[0.62]$ & $2.39 / 39$ & $0.04 / 57$ & 0 & 0 & 0 & 0 \\
\hline$\beta, \varepsilon$-carotene & $424,448,475[0.52]$ & $0.41 / 139$ & $0.01 / 110$ & $1.81 / 214$ & $0.01 / 109$ & $0.50 / 88$ & $0.01 / 93$ \\
\hline$\beta, \beta$-carotene & $454,482[0.17]$ & $0.44 / 110$ & $0.00 / 78$ & 0 & 0 & 0 & 0 \\
\hline 19' HOF & $448,471[0.04]$ & $0.22 / 51$ & $0.00 / 63$ & 0 & 0 & $0.24 / 95$ & $0.01 / 149$ \\
\hline Diatoxanthin & $(430), 454,481[0.36]$ & $0.28 / 245$ & $0.01 / 245$ & 0 & 0 & 0 & 0 \\
\hline Carotenoid mix & $(410), 432,460[0.72]$ & $0.62 / 111$ & $0.01 / 122$ & 0 & 0 & $0.76 / 45$ & $0.02 / 43$ \\
\hline Total pigments/slug & & $132.68 / 44$ & & $212.40 / 157$ & & $83.23 / 47$ & \\
\hline Total PS (w, w/o viola) & & $\begin{array}{r}115.15 \\
105.81\end{array}$ & & $\begin{array}{l}210.13 \\
199.61\end{array}$ & & $\begin{array}{l}75.58, \\
72.06\end{array}$ & \\
\hline Total PC (w, w/o viola) & & $\begin{array}{r}24.53 \\
15.19\end{array}$ & & $12.78,2.26$ & & $10.17,7.19$ & \\
\hline $\begin{array}{l}\text { PS:PC (viola in PS, } \\
\text { viola in PC) }\end{array}$ & & $7.58,4.31$ & & $\begin{array}{l}92.92 \\
15.62\end{array}$ & & $10.51,7.09$ & \\
\hline
\end{tabular}

Mean $\mu \mathrm{g}$ pigment per gram slug (wet weight) and mean $\mu \mathrm{g}$ pigment per $\mu \mathrm{g} \mathrm{chl}$ a. The mean $\mu \mathrm{g}$ pigment per gram slug is also presented as a total $\mu \mathrm{g}$ pigments per gram slug with corresponding ratios of $\mathrm{Chl}$ a to other important pigments or pigment groups. Square brackets indicate ratios between peaks and minima for all pigments, whereas chlorophyll values represent the blue: red ratio. CV\%=coefficient of variation of the mean standard error. $19^{\prime} \mathrm{HOF}=19^{\prime}$ hexanoyloxyfucoxanthin. Photosynthetic (PS) pigments are in bold, photoprotective/carotenoids with low energy transfer efficiency (PC; xanthophyll cycle) are in italic, unassigned (multi-function or unclear) are in bold-italic. Total PC ratios calculated with (w) and without (w/o) violaxanthin since its function varies

\section{Discussion}

In situ observations of Plakobranchus ocellatus indicate that this species prefers open and well-lit, fine grain soft substrates at 1-2 m depth, often close to coral habitats. The macroalgal food sources for this species are not usually observed since they tend to be small and often hidden beneath the sand (Wade and Sherwood 2017). This contrasts with the other species we examined, which are often found on or close to visible detectable macroalgae $(>1 \mathrm{~cm}$ length) and on coral substrates. These contrasts are important when comparing kleptoplast functionality among species and highlight the problems associated with obtaining slugs from dissimilar light habitats. The unique 


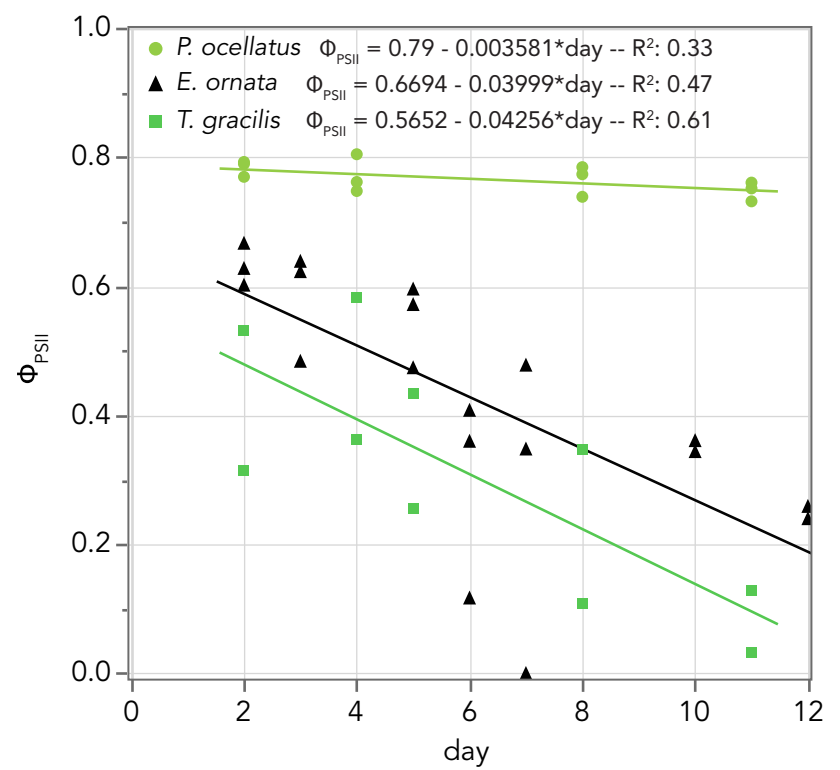

Fig. 2 RFCs for three sacoglossan species during experimental period (11 d, P. ocellatus, T. gracilis; $12 \mathrm{~d}$, E ornata) at LIRS. RFC values were estimated by plotting the $\Phi_{\text {PSII }}$ against time (Evertsen et al. 2007) as per the equation: $R F C=$ initial $\Phi_{P S I I} /$ decreasein $\Phi_{P S I I} d^{-1}$

specimen collection for the experiment in Hawai' $i$ eliminated variability in light habitat, specimen size, seasonal effects, and available food algae, which can greatly influence the original chloroplast photoacclimation status. The results of the $P$. ocellatus light treatment experiment at HIMB provided no evidence that photoacclimation occurred in any of the specimens. We expected signs of photoacclimation to occur most prominently in the low- and/or high-light treatments because these light ranges diverged most from the in situ slug habitat maximum $(\sim 900 \mu \mathrm{mol}$ photons $\mathrm{m}^{-2} \mathrm{~s}^{-1}$ ).

A solar insolation curve illustrates the approximate daily light habitats the specimens experienced during the experiment and puts these in context with the habitat from which they were collected (Supplemental Fig. 1). If kleptoplasts were capable of photoacclimation we would have observed significant signs of photoprotective to photosynthetic ratio shifts and optimization of photosynthetic parameters by day 7 (Hamel and Smith 2020). We found no significant differences in photosynthetic parameters of internal kleptoplasts in any of the treatments during the 7-d period. No significant shifts occurred at numerous known chlorophyte photosynthetic pigment reflectance troughs (absorbance peaks) in the internal kleptoplasts in any of the treatments during the experimental period. Since RLCs were only conducted on internal kleptoplasts, photosynthetic parameters of kleptoplasts lining the undersides of the closed parapodia are unknown. We did, however, measure reflectance of closed parapodia and found a significant effect of increased light intensity exposure over time at all analyzed wavelengths in the $\mathrm{H}$ treatment and at two wavelengths in the $M$ treatment (Fig. 5; Table 3). The increase in reflectance of closed parapodia suggests the kleptoplasts underneath experienced light-induced change consistent with degradation or pigment decrease as a function of time. The increase in the $\mathrm{M}$ treatment indicates a constant requirement for new kleptoplasts even under sub-saturating or natural light conditions. This result was somewhat surprising since the M kleptoplasts should have been acclimated to irradiances above the experimental values. Together with the remarkably stable, low reflectance values of internal kleptoplasts over time, the changes indicate parapodia serve an important photoprotective role for the non-photoacclimating internal kleptoplasts. These results also highlight the importance of burrowing in $P$. ocellatus foraging behavior since this may serve to reduce incident light energy on parapodia, particularly when light is supersaturating. The camouflaging parapodia appear to serve a defensive role, protecting slugs from predation and light intensity and/or prolonged exposure. They permit $P$. ocellatus (RFC=197-203 d) to forage in open, well-lit environments, with access to high-light-acclimated chloroplasts, which contribute to the long-term retention of functional chloroplasts in the species.

The chemotaxonomy results from the Australian LIRS specimens showed that pigment composition and ratios

Table 2 Welch's ANOVA for in vivo photosynthetic parameters $\left(\mathrm{rETR}_{\max }, \mathrm{E}_{\mathrm{k}}, \alpha\right.$, and $\left.\mathrm{F}_{\mathrm{v}} / \mathrm{F}_{\mathrm{m}}\right)$ of internal kleptoplasts comparing effects of treatment at conclusion of experiment (D7; $n=6)$.

\begin{tabular}{|c|c|c|c|c|c|c|c|c|c|c|c|c|c|}
\hline Day & Light & $\begin{array}{l}\mathrm{rETR}_{\max } \\
\text { mean } \pm \mathrm{SD}\end{array}$ & $\mathrm{p}$ & $\begin{array}{l}\text { df } \\
F\end{array}$ & $\begin{array}{l}\mathrm{E}_{\mathrm{k}} \\
\text { mean } \pm \mathrm{SD}\end{array}$ & $\mathrm{p}$ & $\begin{array}{l}\text { df } \\
F\end{array}$ & $\begin{array}{l}\alpha \\
\text { mean } \pm \text { SD }\end{array}$ & $\mathrm{p}$ & $\begin{array}{l}\text { df } \\
F\end{array}$ & $\begin{array}{l}\mathrm{F}_{\mathrm{v}} / \mathrm{F}_{\mathrm{m}} \\
\text { mean } \pm \mathrm{SD}\end{array}$ & $\mathrm{p}$ & $\begin{array}{l}\text { df } \\
F\end{array}$ \\
\hline D1 & & $290 \pm 25$ & & & $639 \pm 309$ & & & $0.66 \pm 0.16$ & & & $0.59 \pm 0.08$ & & \\
\hline D7 & $\mathrm{L}$ & $426 \pm 144$ & 0.09 & & $634 \pm 343$ & 0.10 & & $0.82 \pm 0.16$ & 0.055 & & $0.65 \pm 0.07$ & 0.09 & \\
\hline D7 & M & $349 \pm 30$ & & 2 & $892 \pm 132$ & & 2 & $0.60 \pm 0.07$ & & 2 & $0.60 \pm 0.05$ & & 2 \\
\hline D7 & $\mathrm{H}$ & $298 \pm 50$ & & 3.19 & $561 \pm 346$ & & 3.18 & $0.65 \pm 0.17$ & & 4.17 & $0.53 \pm 0.12$ & & 1.44 \\
\hline
\end{tabular}

Means for baseline measurements $(\mathrm{D} 1 ; n=9)$ included specimens that were later assigned to each treatment. Light treatments; $\mathrm{L}=$ low, $\mathrm{M}=$ medium, $\mathrm{H}=$ high. Mean, standard deviation (SD), and $p$-value reported. 


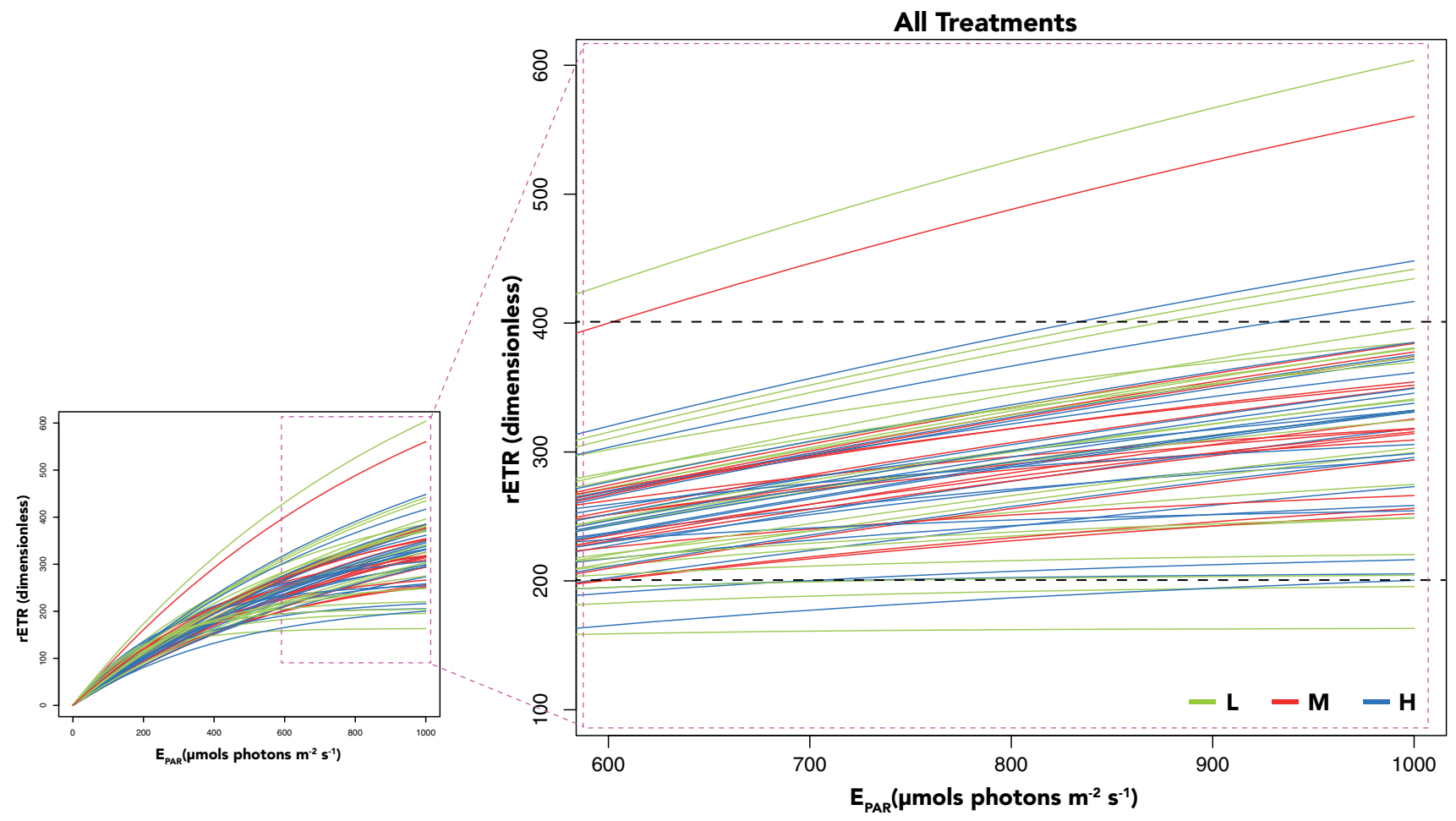

Fig. 3 Relative ETR (rETR) curves detailing 600 to $1000 \mathrm{E}_{\mathrm{PAR}}$ ( $\mu$ mols photons $\mathrm{m}^{-2} \mathrm{~s}^{-1}$ ) with full plot (small, left). Curves for all specimens from three treatments over 7-d experimental period. Most
$\mathrm{rETR}_{\max }$ (at $\mathrm{E}_{\mathrm{PAR}}$ 1000) ranged between 200 and 400 (dimensionless; black dashed lines) with no apparent trends. Area of detail delimited by pink dotted box

Table 3 Means and standard deviation for in vivo reflectance (\%) at several important Chlorophyte wavelength peaks across the visible spectrum for D3 and D7

\begin{tabular}{|c|c|c|c|c|c|c|c|c|c|c|c|c|}
\hline \multirow{7}{*}{ 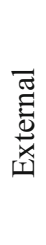 } & Day & Light & $\begin{array}{c}438 \mathrm{~nm} \\
\text { mean } / \mathrm{std} \text { dev }\end{array}$ & $\begin{array}{c}P \\
\text { ChiSq }\end{array}$ & $\begin{array}{c}470 \mathrm{~nm} \\
\text { mean/std dev }\end{array}$ & $\begin{array}{c}P \\
\text { ChiSq }\end{array}$ & $\begin{array}{c}550 \mathrm{~nm} \\
\text { mean/std dev }\end{array}$ & $\begin{array}{c}P \\
\text { ChiSq }\end{array}$ & $\begin{array}{c}645 \mathrm{~nm} \\
\text { mean/std dev }\end{array}$ & $\begin{array}{c}P \\
\text { ChiSq }\end{array}$ & $\begin{array}{c}678 \mathrm{~nm} \\
\text { mean/std dev }\end{array}$ & $\begin{array}{c}P \\
\text { ChiSq }\end{array}$ \\
\hline & D3 & \multirow{2}{*}{$\mathrm{L}$} & $10.39 / 5.29$ & 0.08 & $13.13 / 5.89$ & 0.34 & $23.09 / 6.74$ & 0.63 & $22.33 / 7.10$ & 0.52 & $20.26 / 6.66$ & 0.87 \\
\hline & D7 & & $14.75 / 5.43$ & 3.10 & $16.6 / 5.20$ & 0.92 & $24.71 / 6.35$ & 0.23 & $23.09 / 7.19$ & 0.41 & $20.42 / 6.68$ & 0.03 \\
\hline & D3 & \multirow{2}{*}{ M } & $8.37 / 5.16$ & 0.01 & $10.49 / 5.53$ & 0.01 & $20.81 / 10.46$ & 0.08 & $21.22 / 11.55$ & 0.08 & $19.32 / 10.24$ & 0.055 \\
\hline & D7 & & $22.28 / 8.04$ & 6.56 & $24.11 / 7.65$ & 6.56 & $33.75 / 7.18$ & 3.10 & $33.53 / 7.34$ & 3.10 & $30.62 / 7.61$ & 3.69 \\
\hline & D3 & \multirow{2}{*}{$\mathrm{H}$} & $8.52 / 2.76$ & 0.01 & $10.98 / 3.11$ & 0.03 & $20.09 / 3.79$ & 0.01 & $20.24 / 4.39$ & 0.01 & $18.63 / 4.32$ & 0.01 \\
\hline & D7 & & $16.07 / 4.93$ & 6.56 & $18.73 / 5.65$ & 5.03 & $29.69 / 5.32$ & 6.56 & $30.29 / 5.05$ & 6.56 & $27.45 / 4.02$ & 6.56 \\
\hline \multirow{6}{*}{ 点 } & D3 & \multirow[b]{2}{*}{$\mathrm{L}$} & $5.71 / 4.28$ & 1.0 & $7.21 / 5.83$ & 0.63 & 19.57/9.07 & 0.20 & $9.52 / 5.71$ & 0.26 & $5.42 / 3.82$ & 0.52 \\
\hline & D7 & & $4.60 / 1.75$ & 0.0 & $4.53 / 1.77$ & 0.23 & $12.94 / 5.05$ & 1.64 & $5.64 / 3.08$ & 1.26 & $3.45 / 1.48$ & 0.41 \\
\hline & D3 & \multirow{2}{*}{ M } & $4.24 / 1.74$ & 0.52 & $5.18 / 2.1$ & 0.15 & $13.43 / 5.90$ & 0.34 & $6.53 / 3.26$ & 0.75 & $3.78 / 2.03$ & 0.87 \\
\hline & D7 & & $3.68 / 0.97$ & 0.41 & $3.79 / 1.20$ & 2.08 & $16.49 / 7.18$ & 0.92 & $7.72 / 4.17$ & 0.10 & $3.59 / 1.46$ & 0.03 \\
\hline & D3 & \multirow{2}{*}{$\mathrm{H}$} & $2.89 / 0.74$ & 0.055 & $3.54 / 1.60$ & 0.20 & $17.25 / 7.83$ & 0.34 & $6.96 / 3.07$ & 0.26 & $2.90 / 1.26$ & 0.11 \\
\hline & D7 & & $4.51 / 1.59$ & 3.69 & $4.58 / 1.67$ & 1.64 & $17.17 / 3.60$ & 0.92 & $7.80 / 2.19$ & 1.26 & $4.02 / 1.37$ & 2.56 \\
\hline
\end{tabular}

$P$-values and chi square approximations from the results of nonparametric tests for external kleptoplasts in closed (top) and internal kleptoplasts in open (bottom) parapodia reflectance comparing specimen change from D3 to D7 $(n=6)$. Degrees of freedom $=1$. Abbreviations as in Table 2

varied greatly between the species. Plakobranchus ocellatus had the highest concentration of photosynthetic pigments per wet weight and the highest corresponding concentration of photoprotective pigments among the species, resulting in the lowest photosynthetic: photoprotective (PS:PC) pigment ratios of 4.3 with violaxanthin considered as PC and 7.6 when calculated with PS pigments. These low PS/PC ratios, relative to those for $T$. gracilis (15.6 and 93.0) and E. ornata (7.1 and 10.5), indicate a stronger preference by $P$. ocellatus for highlight-acclimated kleptoplasts (Table 1). Additionally, an antheraxanthin-like carotenoid was present only in $P$. ocellatus, consistent with high-light-acclimated algae. Violaxanthin is strongly light-harvesting and may transfer light energy to reaction center $\mathrm{Chl} a$ under low-light conditions. In high light, decreased lumenal $\mathrm{pH}$ will promote 
de-epoxidation of violaxanthin to initiate the xanthophyll cycle (Brunet et al. 2011). Chemotaxonomy reveals no functional traits in pigments; therefore, we made no definitive determination regarding the primary function of violaxanthin in kleptoplasts. Zeaxanthin was not present in any of the species but this does not necessarily indicate a lack of photoprotective capacity (Goss et al. 1998; Brunet et al. 2011; Christa et al. 2017). Additionally, lutein, a major carotenoid in the Chlorophyta, is considered to be the light-dependent product of conversion from siphonaxanthin and is believed to quench triplet excited chlorophyll $\left({ }^{3} \mathrm{Chl}\right.$; Croce et al. 1999; Baroli et al. 2000; Jahns and Holzwarth 2012). Lutein comprised $6 \%$ of pigments in $P$. ocellatus but was absent in the other two slug species. Its presence in $P$. ocellatus likely augments the VA xanthophyll cycle for photoprotection (Raniello et al. 2006; Christa et al. 2017) while photoprotection in the kleptoplasts of the other two species may not be as vital. Neoxanthin, present in all three species, scavenges the highly destructive singlet oxygen $\left({ }^{1} \mathrm{O}^{*}{ }_{2}\right)$ and thus also plays a role in photoprotection (Niyogi et al. 1997; Croce et al. 1999; Baroli et al. 2000). The apparent preference for kleptoplasts with a lower PS:PC ratio could partially explain the extended kleptoplast functionality in $P$. ocellatus relative to the other species and is a strong indication that these slugs spend time in high-light environments.

Photosynthetic parameter differences among the three LIRS species revealed the importance of the original light conditions on sacoglossan food algae preferences. The light saturation parameter $\left(E_{k}\right)$ values show vast differences in prior photoacclimation status of the kleptoplasts among
Fig. 5 Mean reflectance spectra over time are contrasted between open (a, c, e) and closed parapodia (b, d, f), sorted by low (a, b), medium (c, d), and high (e, f) light treatments $(n=6$ per treatment) per day. Shaded confidence intervals are superimposed on spectrum data smoothed with the Savitzky-Golay filter to reduce noise. Red vertical lines indicate wavelengths where significant differences were found

and within the three species (Table S1), indicating food algae origins from a wide range of light habitats. Thuridilla gracilis individuals $(\mathrm{RFC}=12-14 \mathrm{~d})$ collected from the same habitat and depth (reef flat, sand; 1-2 m) had $\mathrm{rETR}_{\max }$ values ranging from 356 to 1115 , indicating the consumption of chloroplasts from both bright and more shaded microhabitats. A surprising 20-fold difference in $\mathrm{rETR}_{\text {max }}$ occurred between specimens collected in $<2 \mathrm{~m}$ versus 2-8 $\mathrm{m}$ depth. Comparing $E_{k}$ values in kleptoplasts across all species from $1 \mathrm{~m}$ depth, we observed that $T$. gracilis and E. ornata $\left(E_{k} 450-694\right)$ accessed lower-lightacclimated kleptoplasts relative to those in P. ocellatus $\left(E_{k}\right.$ 675-2219). We also observed that light saturation was not reached in several individuals from all three LIRS species and in $P$. ocellatus specimens in Hawai' $i$ and interpreted this as the result of immensely high numbers of kleptoplasts per unit area, a reduction in absorbing cellular components, and minimal effects of self-shading or the "package effect" (Fig. 6).

The concept that $P$. ocellatus keeps its parapodia closed to protect kleptoplasts from excess irradiance is not novel. Indeed, other functional kleptoplast sacoglossans respond to high irradiance by closing their parapodia (Cartaxana
Fig. 4 a In vivo mean reflectance values at $678 \mathrm{~nm}$ (red peak absorption of $\mathrm{Chl}$ a) comparing within treatment response over time for open (green) and closed (black) parapodia. Light values: $\mathrm{L}=$ low $\sim 25-80, \mathrm{M}=$ medium $\sim 255-600$, and $\mathrm{H}=$ high $\sim 880-2100$ in $\mu \mathrm{mol}$ photons $\mathrm{m}^{-2} \mathrm{~s}^{-1} . \mathrm{D}=$ day

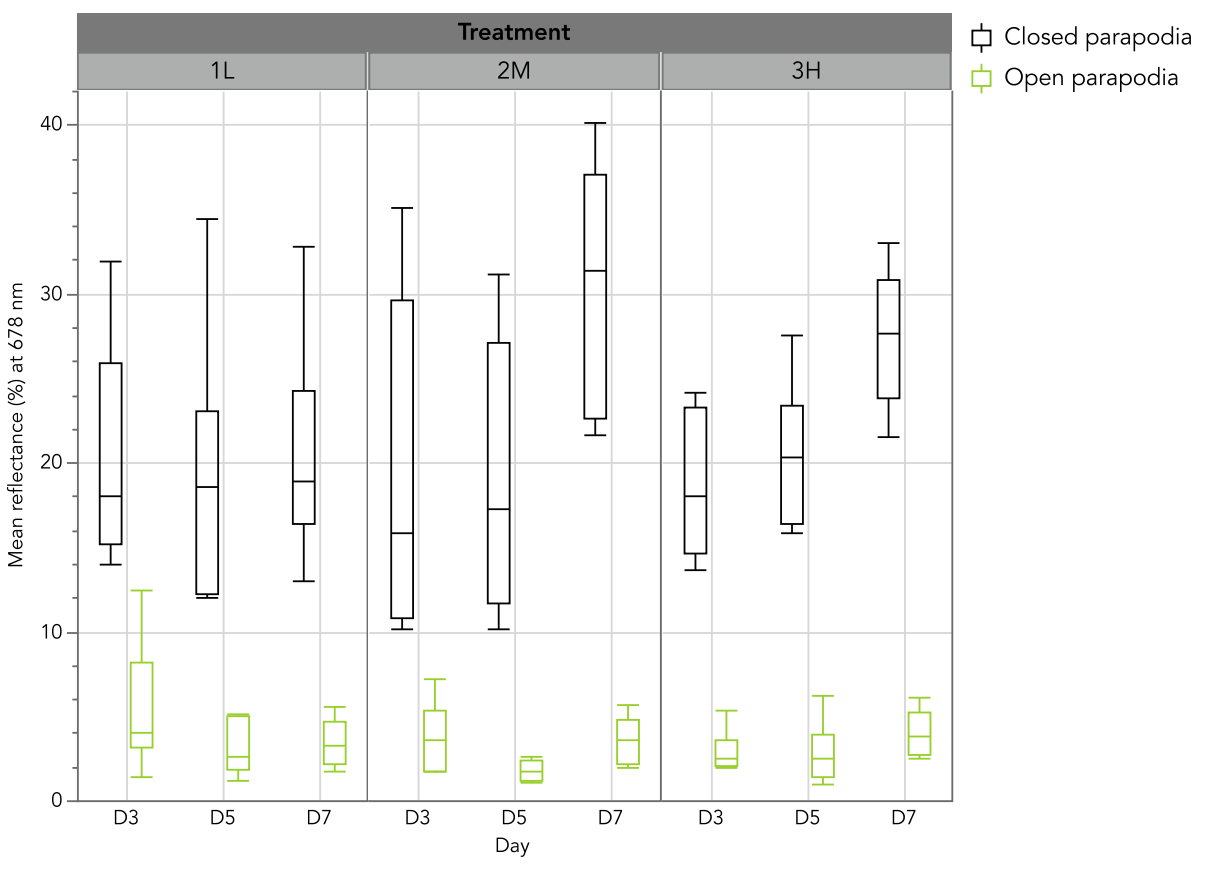



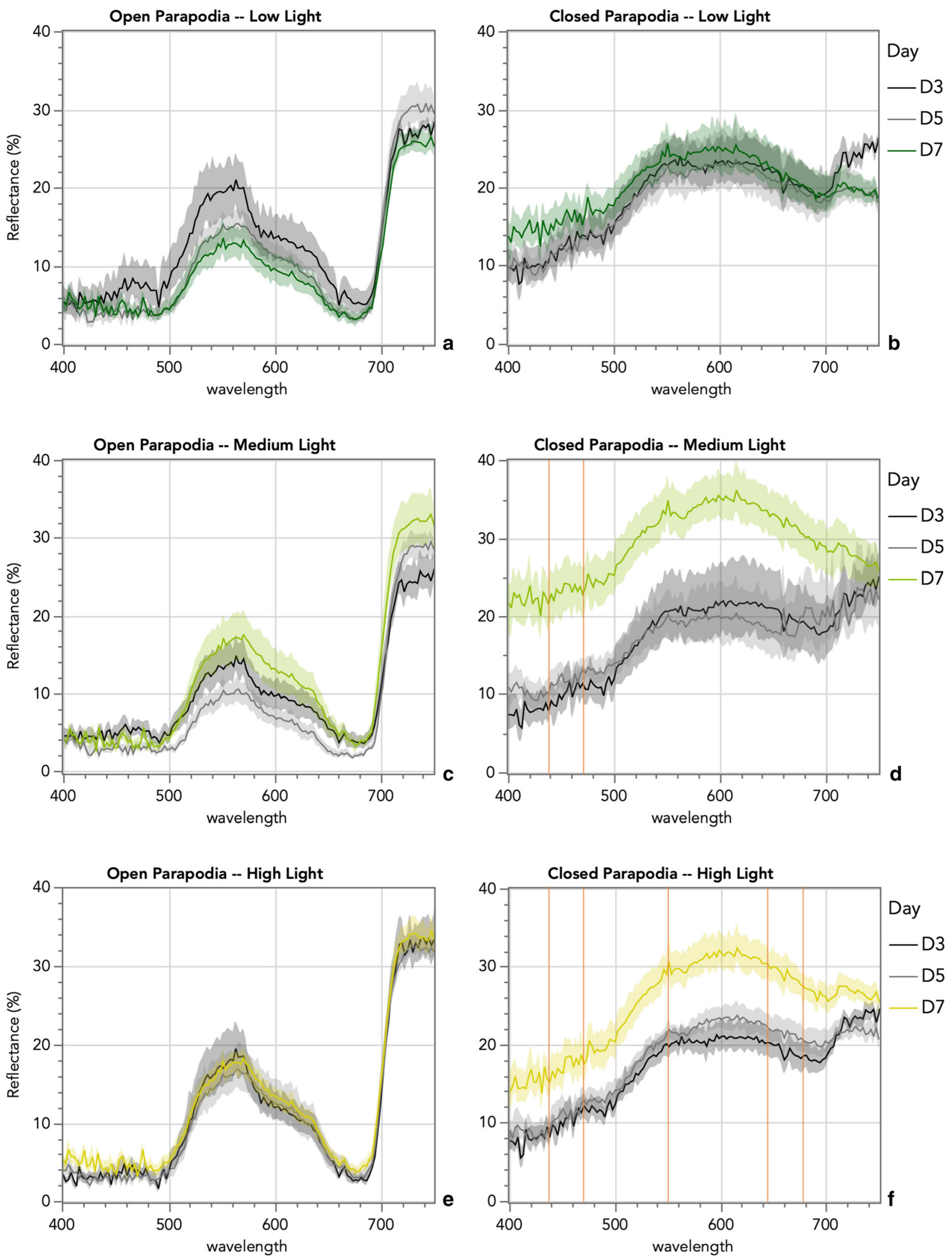


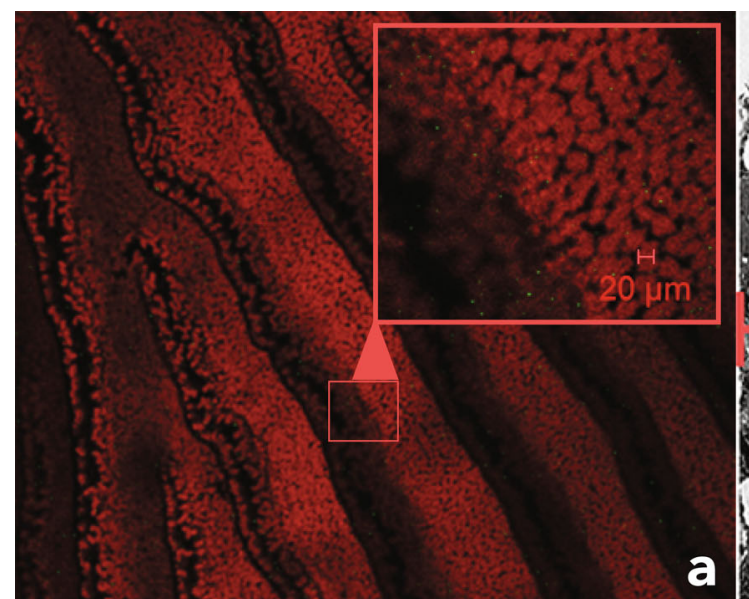

Fig. 6 Kleptoplasts in $P$. ocellatus. a Confocal laser scanning microscopy scan of digestive tubules at $2.5 \times$ magnification with zoomed in area inset. Red color represents fluorescence emission in

et al. 2018, 2019). The novelty lies in the storage containers where copious internal kleptoplasts are located in dorsal lamellae along the central portion of the body, in digestive tubules radiating outward from directly below the heart and stomach toward the tail (Hirose 2005). These unique structures allow the transfer of materials along their length via lumenal microvilli to the distal edges of the digestive glands, located on the undersides of the parapodia (Hirose 2005). These distal kleptoplasts are more exposed and more likely to experience light-induced degradation. The reflectance results strongly indicate these kleptoplasts may be sacrificed and subsequently assimilated to protect the internal kleptoplasts, which may persist and provide food security for up to an estimated $277 \mathrm{~d}$. It is important to note that these long-term estimates are based on a weak linear decline in kleptoplast functionality during short-term experiments and should be tested to verify their accuracy.

Since no evidence of kleptoplast photoacclimation has ever been observed and retention of functional kleptoplasts is presumed important, slugs must avoid light regime change or provide some form of photoprotection. There are two likely strategies that may best explain long-term kleptoplast functionality without photoacclimation. (1) Slugs may restrict movement to shady areas when irradiance is high, remaining close to reef structure, which would also provide cover from predation. This is more likely in "naked" slugs with highly visible kleptoplasts. (2) Slugs with parapodia may cloak their kleptoplasts to avoid highlight exposure. This ability to protect kleptoplasts presumably provides the advantage of unlimited range on reef structure (i.e., coral colonies and coral rubble), sand, or other open spaces. Plakobranchus ocellatus appears to employ this second strategy, as it is commonly found in open, sandy areas, and maintains closed parapodia. The

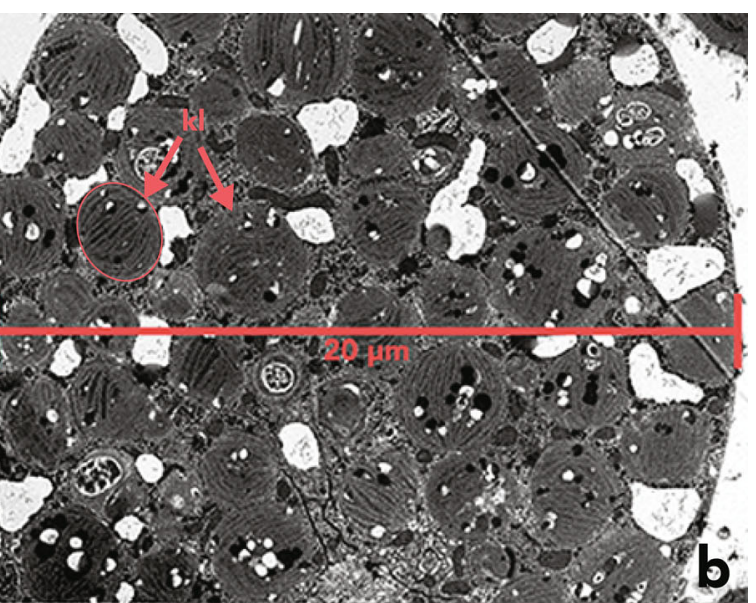

the 568-702 nm range. b Transmission electron microscopy photomicrograph showing numerous kleptoplasts (kl) per unit area. 20 $\mu \mathrm{m}$ size bar for comparison

authors estimate observing over 100 specimens in the field and laboratory (both in Australia and Hawai'i) but never with open parapodia. Unlike the brightly colored or green sacoglossans, the external surface of $P$. ocellatus parapodia are speckled and drab and provide good camouflage in the sand where they have also been observed to burrow. In this manner, P. ocellatus can forage in open areas using crypsis to avoid predators while protecting their internal kleptoplasts from exposure to light. This study provides additional evidence that photosynthetically functional kleptoplasts are sensitive to light intensity changes but do not photoacclimate. We also propose an additional functional role for the camouflaging parapodia, which likely gives $P$. ocellatus an ecological advantage over other reef algae foragers.

Supplementary Information The online version contains supplementary material available at https://doi.org/10.1007/s00338022-02224-z.

Acknowledgements We would like to thank colleagues and staff at the Lizard Island Research Station, Kjersti Andresen at Trondhjem Biological Station for technical assistance with HPLC pigment extraction, Dr. Ku'ulei Rodgers for access to HIMB facilities at the Coral Reef Ecology Lab at HIMB, Dr. Megan Ross for statistical analysis consultation, and Dr. Keisha Bahr for field assistance. This study was supported by the Norwegian Research Council to J. Evertsen (NFR 153790/120). All experiments comply with the current laws of the country in which the experiments were performed. GJ acknowledges Grant from NTNU NV-faculty for 1-y research at University of Hawaii at Manoa (2018-2019) and by the NFR through the Centres of Excellence funding Grant No. 223254-NTNU AMOS. This publication is UH SOEST contribution number 11465 and Hawai' $i$ Institute of Marine Biology contribution number 1873. On behalf of all authors, the corresponding author states that there is no conflict of interest. We also wish to thank our reviewers for thoughtful and constructive suggestions that improved this manuscript. 
Open Access This article is licensed under a Creative Commons Attribution 4.0 International License, which permits use, sharing, adaptation, distribution and reproduction in any medium or format, as long as you give appropriate credit to the original author(s) and the source, provide a link to the Creative Commons licence, and indicate if changes were made. The images or other third party material in this article are included in the article's Creative Commons licence, unless indicated otherwise in a credit line to the material. If material is not included in the article's Creative Commons licence and your intended use is not permitted by statutory regulation or exceeds the permitted use, you will need to obtain permission directly from the copyright holder. To view a copy of this licence, visit http://creativecommons. org/licenses/by/4.0/.

\section{References}

Baker NR (2008) Chlorophyll fluorescence: a probe of photosynthesis in vivo. Ann Rev Plant Biol 59:89-113

Baroli I, Niyogi KK, Barber J, Heifetz P (2000) Molecular genetics of xanthophyll-dependent photoprotection in green algae and plants. Philos Trans R Soc B Biol Sci 355:1385-1394

Beach KS, Borgeas HB, Smith CM (2006) Ecophysiological implications of the measurement of transmittance and reflectance of tropical macroalgae. Phycologia 45(4):450-457

Brunet C, Johnsen G, Lavaud J, Roy S (2011) Pigments and photoacclimation processes. In: Roy S, Llewellyn CA, Egeland ES, Johnsen G (eds) Phytoplankton pigments: characterization, chemotaxonomy and applications in oceanography. Cambridge University Press, Cambridge, pp 445-471

Cartaxana P, Morelli L, Quintaneiro C, Calado G, Calado R, Cruz S (2018) Kleptoplast photoacclimation state modulates the photobehavior of the solar-powered sea slug Elysia viridis. J Exp Biol 221:1-5. https://doi.org/10.1242/jeb.180463

Cartaxana P, Morelli L, Jesus B, Calado G, Calado R, Cruz S (2019) The photon menace: Kleptoplast protection in the photosynthetic sea slug Elysia timida. J Exp Biol 222:3-8

Christa G, Cruz S, Jahns P, de Vries J, Cartaxana P, Esteves AC, Serôdio J, Gould SB (2017) Photoprotection in a monophyletic branch of chlorophyte algae is independent of energy-dependent quenching (qE). New Phytol 214:1132-1144

Christa G, Händeler K, Schäberle TF, König GM, Wägele H (2014) Identification of sequestered chloroplasts in photosynthetic and non-photosynthetic sacoglossan sea slugs (Mollusca, Gastropoda). Front Zool 11:1-12

Croce R, Weiss S, Bassi R (1999) Carotenoid-binding sites of the major light-harvesting complex II of higher plants. J. Biol Chem 274:29613-29623

Cruz S, LeKieffre C, Cartaxana P, Hubas C, Thiney N, Jakobsen S, Escrig S, Jesus B, Kühl M, Calado R, Meibom A (2020) Functional kleptoplasts intermediate incorporation of carbon and nitrogen in cells of the Sacoglossa sea slug Elysia viridis. Sci Rep 10:1-12

DeWreede R (2006) Biomechanical properties of coenocytic algae (Chlorophyta, Caulerpales). Sci Asia Suppl 1:57-62

Escoubas JM, Lomas M, LaRoche J, Falkowski PG (1995) Light intensity regulation of cab gene transcription is signaled by the redox state of the plastoquinone pool. Proc Natl Acad Sci USA 92:10237-10241

Evertsen J, Burghardt I, Johnsen G, Wägele H (2007) Retention of functional chloroplasts in some sacoglossans from the indopacific and mediterranean. Mar Biol 151:2159-2166

Evertsen J, Johnsen G (2009) In vivo and in vitro differences in chloroplast functionality in the two north Atlantic sacoglossans
(Gastropoda, Opisthobranchia) Placida dendritica and Elysia viridis. Mar Biol 156:847-859

Falkowski PG, Chen Y-B (2003) Photoacclimation of light harvesting systems in Eukaryotic algae. In: Green BR, Parson WW (eds) Light-harvesting antennas in photosynthesis. Springer, Dordrecht, pp 423-447

Falkowski PG, Owens TG (1980) Light-Shade Adaptation: Two strategies in marine phytoplankton. Plant Physiol 66:592-595

Falkowski PG, Raven JA (2007) Aquatic photosynthesis. Princeton University Press, Princeton

Genty B, Briantais J-M, Baker NR (1989) The relationship between the quantum yield of photosynthetic electron transport and quenching of chlorophyll fluorescence. Biochim Biophys Acta 90:87-92

Goss R, Böhme K, Wilhelm C (1998) The xanthophyll cycle of Mantoniella squamata converts violaxanthin into antheraxanthin but not to zeaxanthin: consequences for the mechanism of enhanced non-photochemical energy dissipation. Planta 205:613-621

Hamel K, Smith CM (2020) Comparative time-courses of photoacclimation by Hawaiian native and invasive species of Gracilaria (Rhodophyta). Aquat. Bot. 163:103210

Händeler K, Grzymbowski YP, Krug PJ, Wägele H (2009) Functional chloroplasts in metazoan cells - a unique evolutionary strategy in animal life. Front. Zool. 6:1-18

Hirose E (2005) Digestive system of the sacoglossan Plakobranchus ocellatus (Gastropoda: Opisthobranchia): Light- and electronmicroscopic observations with remarks on chloroplast retention. Zoolog Sci 22:905-916

Jahns P, Holzwarth AR (2012) The role of the xanthophyll cycle and of lutein in photoprotection of photosystem II. Biochim Biophys Acta - Bioenerg 1817:182-193

Jeffrey SW, Mantoura RF, Bjørnland T (1997) Data for the identification of $47 \mathrm{key}$ phytoplankton pigments. In: Jeffrey SW, Mantoura RFC, Wright S (eds) Phytoplankton pigments in oceanography: guidelines to modern methods. UNESCO, Paris, pp 449-559

Jensen KR (1993) Morphological adaptations and plasticity of radular teeth of the Sacoglossa ( = Ascoglossa) (Mollusca: Opisthobranchia) in relation to their food plants. Biol J Linn Soc 48:135-155

Jensen KR (1997) Evolution of the Sacoglossa (Mollusca, Opisthobranchia) and the ecological associations with their food plants. Evol Ecol 11:301-335

Jesus B, Ventura P, Calado G (2010) Behaviour and a functional xanthophyll cycle enhance photo-regulation mechanisms in the solar-powered sea slug Elysia timida (Risso, 1818). J Exp Mar Bio Ecol 395:98-105

Johnsen G, Sakshaug E (2007) Biooptical characteristics of PSII and PSI in 33 species (13 pigment groups) of marine phytoplankton, and the relevance for pulse-amplitude-modulated and fastrepetition-rate fluorometry. J Phycol 43:1236-1251

Kirk JTO (2011) Light and photosynthesis in aquatic ecosystems, 3rd edn. Cambridge University Press, New York

Krause GH, Weis E (1991) Chlorophyll fluorescence and photosynthesis: the basics. Annu. Rev. Plant Physiol. Plant Mol. Biol. 42:313-349

Kroon B, Prézelin BB, Schofield O (1993) Chromatic regulation of quantum yields for Photosystem II charge separation, oxygen evolution, and carbon fixation in Heterocapsa Pygmaea (Pyrrophyta). J. Phycol. 29:453-462

Krug PJ, Vendetti JE, Rodriguez AK, Retana JN, Hirano YM, Trowbridge CD (2013) Integrative species delimitation in photosynthetic sea slugs reveals twenty candidate species in three nominal taxa studied for drug discovery, plastid symbiosis or biological control. Mol Phylogenet Evol 69:1101-1119 
Leliaert F, Smith DR, Moreau H, Herron MD, Verbruggen H, Delwiche CF, De Clerck O (2012) Phylogeny and molecular evolution of the green algae. CRC Crit Rev Plant Sci 31:1-46

Marín A, Ros JD (1992) Dynamics of a peculiar plant-herbivore relationship: the photosynthetic ascoglossan Elysia timida and the chlorophycean Acetabularia acetabulum. Mar. Biol.

Martín-Hervás MdR, Carmona L, Malaquias MAE, Krug PJ, Gosliner TM, Cervera JL (2021) A molecular phylogen of Thuridilla Bergh, 1872 sea slugs (Gastropoda, Sacoglossa) reveals a case of flamboyant and cryptic radiation in the marine realm. Cladistics. doi: https://doi.org/10.1111/cla.12465

Niyogi KK, Björkman O, Grossman AR (1997) The roles of specific xanthophylls in photoprotection. Proc Natl Acad Sci USA 94:14162-14167

Pierce SK, Biron RW, Rumpho ME (1996) Endosymbiotic chloroplasts in molluscan cells contain proteins synthesized after plastid capture. J Exp Biol 199:2323-2330

Pierce SK, Curtis NE, Middlebrooks ML (2015) Sacoglossan sea slugs make routine use of photosynthesis by a variety of speciesspecific adaptations. Invertebr Biol 134:103-115

Pierce SK, Curtis NE, Schwartz JA (2009) Chlorophyll a synthesis by an animal using transferred algal nuclear genes. Symbiosis 49:121-131

Raniello R, Lorenti M, Brunet C, Buia MC (2006) Photoacclimation of the invasive alga Caulerpa racemosa var. cylindracea to depth and daylight patterns and a putative new role for siphonaxanthin. Mar Ecol 27:20-30

Raven JA, Beardall J, Flynn KJ, Maberly SC (2009) Phagotrophy in the origins of photosynthesis in eukaryotes and as a complementary mode of nutrition in phototrophs: Relation to Darwin's insectivorous plants. J Exp Bot 60:3975-3987

Rodríguez F, Chauton M, Johnsen G, Andresen K, Olsen LM, Zapata M (2006) Photoacclimation in phytoplankton: Implications for biomass estimates, pigment functionality and chemotaxonomy. Mar Biol 148:963-971

Rowan KS (1989) Photosynthetic pigments of algae. Cambridge University Press, Cambridge

Roy S, Llewellyn C, Egeland ES, Johnsen G (2011) Phytoplankton pigments: Updates on characterization, chemotaxonomy and applications in oceanography. Cambridge Environmental Chemistry Series. Cambridge University Press, Cambridge

Sakshaug E, Bricaud A, Dandonneau Y, Falkowski PG, Kiefer DA, Legendre L, Morel A, Parslow J, Takahashi M (1997) Parameters of photosynthesis: definations, theory and interpretation of results. J Plankton Res 19:1637-1670

Serôdio J, Pereira S, Furtado J, Silva R, Coelho H, Calado R (2010) In vivo quantification of kleptoplastic chlorophyll $a$ content in the "solar-powered" sea slug Elysia viridis using optical methods: spectral reflectance analysis and PAM fluorometry. Photochem Photobiol Sci 9:68-77
Serôdio J, Cruz S, Cartaxana P, Calado R (2014) Photophysiology of kleptoplasts: Photosynthetic use of light by chloroplasts living in animal cells. Philos Trans R Soc B Biol Sci. 369:20130242

Sukenik A, Bennett J, Mortain-Bertrand A, Falkowski PG (1990) Adaptation of the photosynthetic apparatus to irradiance in Dunaliella tertiolecta: A kinetic study. Plant Physiol. 92:891-898

Taiz L, Zeiger E (2010) Plant Physiology. Sinauer Publishing, Sunderland, MA, USA

Trench RK, Greene RW, Bystrom BG (1969) Chloroplasts as functional organelles in animal tissues. J. Cell Biol. 42:404-17

Trench RK, Ohlhorst S (1976) The stability of chloroplasts from siphonaceous algae in symbiosis with sacoglossan molluscs. New Phytol 76:99-109

Vieira S, Calado R, Coelho H, Serôdio J (2009) Effects of light exposure on the retention of kleptoplastic photosynthetic activity in the sacoglossan mollusc Elysia viridis. Mar Biol 156:1007-1020

Wade RM, Sherwood AR (2017) Molecular determination of kleptoplast origins from the sea slug Plakobranchus ocellatus (Sacoglossa, Gastropoda) reveals cryptic bryopsidalean (Chlorophyta) diversity in the Hawaiian Islands. J Phycol 53:467-475

Wade RM, Sherwood AR (2018) Updating Plakobranchus cf. ianthobapsus (Gastropoda, Sacoglossa) host use: Diverse algalanimal interactions revealed by NGS with implications for invasive species management. Mol Phylogenet Evol 128:172-181

Wägele H, Johnsen G (2001) Observations on the histology and photosynthetic performance of "solar-powered" opisthobranchs (mollusca, gastropoda, opisthobranchia) containing symbiotic chloroplasts or zooxanthellae. Org Divers Evol 1:193-210

Walker DA (1970) Three phases of chloroplast research. Nature 226:1204-1208

Webb WL, Newton M, Starr D (1974) Carbon dioxide exchange of Alnus rubra - a mathematical model. Oecologia 17:281-291

Yokohama Y (1981) Distribution of the green light-absorbing pigments siphonaxanthin and siphonein in marine green algae. Bot Mar 24:637-640

Yonow N, Jensen KR (2018) Results of the rumphius biohistorical expedition to Ambon (1990). Part 17. The cephalaspidea, anaspidea, pleurobranchida, and sacoglossa (mollusca: Gastropoda: Heterobranchia). Arch fur Molluskenkd 147:1-48

WoRMS (World Register of Marine Species). http://www.marinespe cies.org. Last accessed on May 12, 2021

Publisher's Note Springer Nature remains neutral with regard to jurisdictional claims in published maps and institutional affiliations. 